Received: 19 July 2021 Accepted: 23 December 2021

\title{
Eating Upon the Mountains: Deviant Consumption and Commensality
}

\section{Rebekah Welton $^{1}$}

\begin{abstract}
This article uses sociological and anthropological approaches to assess cases of deviant consumption in Hebrew Bible texts. Drawing together key concepts such as commensality and deviance, the importance of eating within the bounds of culturally constructed norms is emphasised. Food is a significant part of material culture that assists in the construction of individual and group identities. Consequently, deviation from normative food habits has serious ramifications on group identity and cohesion. For authors of Hebrew Bible texts, eating in a way that did not render Yahweh jealous was a key aspect of eating practices that were deemed acceptable. These practices included shared meals between human and divine participants, and the proper sharing of food within Yahweh's cult. By focusing on the social reaction to certain deviant consumption events, the deviantisation processes used by the authors of ancient Hebrew texts are highlighted, rather than asserting the existence of any inherent "wrong."
\end{abstract}

Keywords: Hebrew Bible; Deviance; Food; Commensality; Yahweh; Anthropology; Sociology

Eating is a necessary biological function for all living beings, but it is also a key activity that contributes to the construction and maintenance of social bonds and identity. ${ }^{2}$ Eating as part of a wider unit thus enables the formation of group identity, which in turn can contribute to more expansive notions of cultural or even national identities. As such, any eating which fails to conform to the social

\footnotetext{
${ }^{1}$ Rebekah Welton, University of Exeter, UK. E-mail: r.c.welton@exeter.ac.uk.

${ }^{2}$ I would like to thank Louise Lawrence for her helpful feedback on a draft version of this article.
} 


\section{Eating Upon the Mountains: Deviant Consumption and Commensality}

group's normative foodways ${ }^{3}$ may well contribute to an identity that diverges from the majority, and thus may be regarded negatively by the wider group. In ancient Israelite and Judahite cultures, this negative reaction to eating by individuals or marginal groups is what I term "deviant consumption." It is the phenomenon of eating or drinking occurrences found in Hebrew Bible texts that have been rendered deviant by the texts' authors. In this article, I will establish the theoretical underpinning of deviant consumption using insights from the fields of sociology, anthropology and food studies before turning to an assessment of several case studies of deviant consumption in ancient Hebrew texts.

\section{Defining Deviance}

Deviance is deviation from the norm. But the norm is established by those with the power to state what is normative and thus acceptable. Social scientist Erving Goffman characterises social deviants as those who are seen to be "declining voluntarily" their "social place" and are "rebellious" against "basic institutions." They engage in a "collective denial of the social order," they ignore the culturally and politically "approved runways" and "motivational schemes of society," and do not convey the respect deemed appropriate to those above them. ${ }^{4}$ The term deviance is not absolutist. When sociologists talk about deviance it is not a discussion about what is inherently right or wrong. Instead, deviance refers to a negative reaction by a social group to those they deem to violate socially accepted norms in behaviour and belief. ${ }^{5}$ The sociologist is interested in why a society reacts to perceived deviance and how it deals with it; what power dynamics exist in the deviantisation process and how broader socio-

\footnotetext{
${ }^{3}$ Foodways are the culturally specific activities and meanings associated with food including diet, agriculture, pastoralism, slaughter, cooking, preserving, consumption, hospitality, feasting, and the identities and roles associated with these processes. See Christine Hastorf, The Social Archaeology of Food (Cambridge: Cambridge University, 2017), 14.

${ }^{4}$ Erving Goffman, Stigma: Notes on the Management of a Spoiled Identity (Englewood Cliffs: Prentice-Hall, 1963), 143-4.

5 Robin D. Perrin, "Cognitive Deviance: Unconventional Beliefs," in The Handbook of Deviance (Hoboken: Wiley-Blackwell, 2015), 404.
} 
political contexts might contribute to the reactions of the group. ${ }^{6}$ The study of deviance asks us to question why certain people are stigmatised in certain times and places and what effects it has both on the deviantised and the group who confers the label "deviant" onto them. The study of deviance in the discipline of sociology is particularly helpful for understanding cultural boundaries:

...members of a community inform one another about the placement of their boundaries by participating in the confrontations which occur when persons who venture out to the edges of the group are met by policing agents whose special business it is to guard the cultural integrity of the community. Whether these confrontations take the form of criminal trials, excommunication hearings, courts-martial, or even psychiatric case conferences, they act as boundarymaintaining devices in the sense that they demonstrate to whatever audience is concerned where the line is drawn between behavior that belongs in the special universe of the group and behavior that does not. ${ }^{7}$

When confrontations occur between opposing ideological positions, the drama that follows and the resolutions that emerge constitute a negotiation of group boundaries, and some individuals may subsequently find themselves on the outside of those new delineations. When deviant behaviours construct the outer edges of a cultural group, the inner structure is thus framed and ordered, (re-)asserting the cultural identity and values of the community.

\section{Deviant Consumption}

The behaviour on which this article is focusing in relation to deviancy is consumption. Food and eating are a unique aspect of culture in two key ways. First, food is a form of material culture which is ingested and destroyed preventing re-circulation, as identified by

\footnotetext{
'Pat Lauderdale, "Political Deviance," in The Handbook of Deviance (Hoboken: Wiley-Blackwell, 2015), 528.

${ }^{7}$ Kai T. Erikson, Wayward Puritans: A Study in the Sociology of Deviance (New York: John Wiley \& Sons, 1966), 11.
} 
anthropologist Michael Dietler. ${ }^{8}$ Second, it is the most base action for all humans, making it the most shared action, giving rise to its sociological significance, according to the German sociologist Georg Simmel. ${ }^{9}$ Perhaps paradoxically, eating is thus simultaneously highly personal and highly communal. As "embodied material culture," food has a transformative effect on the human body via ingestion, and thus has a uniquely intimate relationship with the consumer making it a potent inculcator of identity and personhood. ${ }^{10}$ Yet, eating is not private. In fact, the behaviour that is most common between people is eating, and this is because it is the lowest common denominator, or most "primitive" aspect, of our nature. ${ }^{11}$ Consequently, as Simmel states, the pervasiveness of eating as a shared behaviour is the very reason for "the immense sociological significance of the meal."12 At shared meals food allows individuals to locate themselves and others within a particular social context through participation in habitual, highly ordered patterns of food production and consumption. ${ }^{13}$ Consequently, communal eating contributes to not only individual identity but also to the establishment and recognition of others with whom you might identify in a social group.

The identities that food creates within cultural contexts include gender, status, class, and national to name a few. For example, anthropologist Carole Counihan has recorded the perceived notions among young Americans in the nineties that "lighter" foods like chicken and salad are "female foods" while "heavier" foods, like beef and potatoes, are seen as "male," and that the genders should be cognizant of this in order to eat "appropriately." 14 More recently, Katharina Vester has analysed the discourses of food in a range of

\footnotetext{
${ }^{8}$ Michael Dietler, "Culinary Encounters: Food, Identity, and Colonialism," in The Archaeology of Food and Identity (Carbondale: Southern Illinois University, 2007), 222.

${ }^{9}$ For a translation of Simmel's 1957 essay see Michael Symons, "Simmel's Gastronomic Sociology: An Overlooked Essay," Food and Foodways 5 (1994): 346.

${ }^{10}$ Dietler, "Culinary Encounters: Food, Identity, and Colonialism,” 222.

11 Symons, "Simmel’s Gastronomic Sociology," 346.

${ }^{12}$ Symons, "Simmel's Gastronomic Sociology," 346.

${ }^{13}$ Dietler, "Culinary Encounters: Food, Identity, and Colonialism,” 225.

${ }_{14}$ Carole M. Counihan, The Anthropology of Food and Body: Gender, Meaning, and Power (New York: Routledge, 1999), 124-5.
} 
American writings, and demonstrates how texts promoting men's cooking in the 1890s - 1970s constructed "ideal" masculinity. ${ }^{15}$ A notable example being Hemingway's assertion that any average man can make a pie at least as good as his wife, a move, according to Vester, to oppose women's culinary authority and influence. ${ }^{16}$ Vester also identifies voices of resistance in the recipe books of lesbian women who seek to use food and memoires to undermine the hegemonic norm that cooking is the way women express love to their husbands and children. ${ }^{17}$ In observing the eating habits of the Samburu of Northern Kenya, Jon Holtzman documents how the distribution and consumption of particular foods serves to structure Samburu social life, particularly in the delineation and statusmaintenance of the warrior group (murran). ${ }^{18}$ Sugar consumption in eighteenth century England offers a pertinent example of how emulating the eating of upper class groups by the poor was a method of improving one's own class standing and privilege. ${ }^{19}$ Ethnographic work conducted by David Sutton on the food of the island of Kalymnos near Greece reveals how national and local foods can become key markers of identity at different levels. Take for example the national significance of Greek feta made from ewe's milk (versus the cow milk feta of Denmark), or the disagreement over what constitutes Greek bean soup depending on the regional identities of those debating. ${ }^{20}$ Greek foods also become vital for the maintenance of those identities should individuals migrate to new unfamiliar countries as it enables them to feel connected to their home communities through consumption of foods they know their families are also enjoying miles away. ${ }^{21}$ These diverse examples, though not exhaustive, demonstrate how food is entangled in the process of identity formation of individual eaters. Participating in eating with

\footnotetext{
${ }^{15}$ Katharina Vester, A Taste of Power: Food and American Identities (Oakland: University of California Press, 2015), 66-136.

${ }^{16}$ Vester, $A$ Taste of Power, 89.

${ }_{17}$ Vester, A Taste of Power, 137-195.

${ }^{18}$ Jon Holtzman, Uncertain Tastes: Memory, Ambivalence, and the Politics of Eating in Samburu, Northern Kenya (Berkeley: University of California, 2009), 69-93.

${ }^{19}$ Sydney W. Mintz, Sweetness and Power: The Place of Sugar in Modern History (London: Penguin, 1986), 173.

${ }^{20}$ David Sutton, Remembrance of Repasts: An Anthropology of Food and Memory (Oxford: Berg, 2001) 85-86.

${ }^{21}$ Sutton, Remembrance of Repasts, 87.
} 
others then means that acts of consumption also contribute to much larger collective identities which are marked and closely regulated by those communities.

An illuminating report on the consumer habits among hipsters is particularly useful for understanding how groups may utilise food in the formation of a distinct group identity. ${ }^{22}$ The "hipster community" is reportedly at odds with mass-produced goods, prefers independent, local goods and markets, and is generally antiestablishment in ethos and expression of style. Because of the dominance of food in everyday life, it is one of the key ways groups like hipsters may resist broader mass consumerism. In the report, several strategies are described based on ethnographic observations and interviews conducted with self-identified mid-twenties hipsters. At shared group meals distinct effort is made to intentionally subvert traditional norms by rejecting any formal presentation or etiquette and refusing to serve "boring" frozen foods like pizza. They make sure that the food is imbued with increased amounts of labour by cooking from scratch with ideally local or organic ingredients, which are generally more expensive. ${ }^{23}$ This kind of cooking or baking is felt to express their unique identity, distinct from the "uniformity" of outsiders. A similar strategy is to avoid mainstream convenience brands that are perceived to be consumed only by people who are "part of the rat race.",

In their choice of alcohol consumption, "underdog" beer brands that are culturally associated with "homeless people" and "bums" are prioritised in protest of more mainstream, middle-class drinks to also bolster the hipster identity and status. ${ }^{25}$ Thus, the hipster's food identity draws on very specific, if opposing, cultural symbols: the expensive organic food of the local farmers' market and the cheap booze of the poor and marginalised. The highly regulated way in

\footnotetext{
22 James M. Cronin, Mary B. McCarthy \& Alan M. Collins, "Covert Distinction: How Hipsters Practice Food-based Resistance Strategies in the Production of Identity," Consumption Markets \& Culture 17 (2014): 2-28.

${ }^{23}$ Cronin et al., "Covert Distinction," 11, 16-17.

${ }^{24}$ Cronin et al., "Covert Distinction," 18.

${ }^{25}$ Cronin et al., "Covert Distinction," 19.
} 
which food and drink is chosen, prepared and consumed in the group serves to not only communicate personal identity but also prevents infiltration by those who are not authentically hipster:

food is a material for identity enactment within the hipster community - a symbolic object for group consumption where the shared identity is formed, confirmed and strengthened, and where status is developed and displayed. It might also be argued that it is the embedded role of food in identity formation that the hipster can be separated from the pretender or hipster mythology. ${ }^{26}$

The hipsters' use of food draws very sharp boundaries between themselves and those perceived to be mainstream, inauthentic, outsiders. In eating together, the group collectively reinforces and develops their ideological commitments to the hipster identity. The meals thus perpetuate the continued integrity of the group in the face of surrounding and ever encroaching ideological opposition. Given the integral role of food in identity construction and maintenance, food is thus also likely to be integral in cases of deviant identities. Indeed, as the above case illustrates those who do not abide by the hipster norms of consumption are regarded as "unenlightened" or "superficial imitators." 27 This reaction is perhaps illustrative of the way in which a regulated group may apply stigmatising labels to nonconformers as a form of boundary maintenance.

In cases where a group is the majority and/or wields political and cultural power, their boundary maintaining actions and discourses may be considered deviantising. ${ }^{28}$ The group under consideration in this article comprises of the authors of Hebrew Bible texts who as literate, elite, males had the power to construct deviantising discourses relating to consumption practices. Reported episodes of eating and drinking which are negatively sanctioned may be regarded

\footnotetext{
${ }^{26}$ Cronin et al., "Covert Distinction," 23.

${ }^{27}$ Cronin et al., "Covert Distinction," 25.

${ }^{28}$ Daniel Dotter, "The Process of Deviantization," in The Handbook of Deviance (Hoboken: WileyBlackwell, 2015), 110; Perrin, "Cognitive Deviance," 410-411; Druann Maria Heckert and Daniel Alex Heckert, "Positive Deviance," in The Handbook of Deviance (Hoboken: Wiley-Blackwell, 2015), 94.
} 
in themselves as boundary maintaining devices that seek to broadcast to the audience where the line is drawn. There are also cases preserved in the biblical texts that demonstrate how deviant consumers may have been treated by their wider community.

\section{Deviant Consumption and the Hebrew Bible}

\section{Deviant Eating with “Other” Gods}

Several texts recount episodes of consumption that are negatively sanctioned by the author(s) and thus may provide illustrations of deviant consumption in the Hebrew Bible. In Numbers 25 Yahweh's anger becomes threatening to the Israelites after they participate in shared consumption in Moab:

...the people began to whore (לזנת) with the women of Moab. ${ }^{29}$ These invited the people to the sacrifices of their gods, and the people ate and bowed down to their gods. Thus Israel yoked itself to Ba'al Peor, and Yahweh's anger was kindled against Israel. Yahweh said to Moses, "Take all the chiefs of the people, and impale them facing the sun before Yahweh, in order that the fierce anger of Yahweh may turn away from Israel." And Moses said to the judges of Israel, "Each of you shall kill any of your people who have yoked themselves to Ba'al Peor." 30 (Num 25:1-5)

The Israelites eat of the sacrificial meals made to a deity that was not Yahweh, and the text directly links this eating to the formation of some kind of relationship or bond with Ba'al Peor; "Israel yoked itself to Ba'al Peor." This eating and yoking expresses what we might otherwise refer to as commensality; the sharing of food, which creates kinship bonds. Social scientist Claude Fischler comments that "commensality is both inclusive and exclusive: it creates and/or

\footnotetext{
29 In relation to the translation of לזנת Jessie DeGrado states: "more archaic English terms (such as 'harlot') often obscure the obscenity of the Hebrew text and, in many cases, renders sexual violence against women more palatable." Jessie DeGrado, "The qdesha in Hosea 4:14: Putting the (Myth of the) Sacred Prostitute to Bed," Vetus Testamentum 68 (2018): 10 n. 5.

${ }^{30}$ Translations my own unless stated otherwise.
} 
sanctions inclusion (even transient inclusion) in a group or community, as well as exclusion of those not taking part." 31 In the case of the Israelites, their inclusion in the consumption activities of the Moabite women and their deity simultaneously excludes Yahweh from that socially constructive action, which he cannot abide. Moses recognises the effect this exclusionary commensality has on Yahweh, and takes action to remedy the situation.

A similar scenario is imagined in Exodus 34 where the Israelites are commanded to destroy the altars, standing stones, and asherahs of the promised land's inhabitants, or else they will be invited to share in the eating of the sacrifices to the non-Yahwistic gods (vv. 14-16). This is a problem for Yahweh, who is not only described as "a jealous god," but his name is "Jealous" (v. 14) - we have here a whole new meaning of food envy! The language of "whoring," used in both these texts, is one of the ways in which these eaters are deviantised, לזנת being a stigmatising and pejorative term for worship authors deem illegitimate. ${ }^{32}$ However, what is key to the construction of this gustatory deviance is its portrayal as dangerous to the community because of the harm Yahweh may inflict on Israel as a result. The writers demonstrate to their audience, whoever that may be, that this form of consumption is a threat to the continued survival of the nation by reporting this event from the mythological past in order that it may establish effective community boundaries in their contemporary context.

The metaphysical belief underpinning the deviant consumption so far discussed is that deities or other divinised beings were understood to participate in meals and feasts, particularly, though not only, when these were sacrificial in nature. ${ }^{33}$ Additionally, divinised ancestors

\footnotetext{
${ }^{31}$ Claude Fischler, “Commensality, Society and Culture," Social Science Information 50 (2011): 533.

32 Irene E. Riegner, The Vanishing Hebrew Harlot: The Adventures of the Hebrew Stem ZNH (New York: Peter Lang, 2009), 4.

${ }^{33}$ Cynthia Shafer-Elliott, "The Role of the Household in the Religious Feasting of Ancient Israel and Judah," in Feasting in the Archaeology and Texts of the Bible and the Ancient Near East (University Park: Penn State, 2021), 217; Anne Katrine de Hemmer Gudme, "If I were hungry, I would not tell you' (Ps 50, 12): Perspectives on the Care and Feeding of the Gods in the Hebrew Bible," Scandinavian Journal of the Old Testament 28 (2014): 176-7.
} 
were also understood to be present recipients of food at household meals. ${ }^{34}$ As a result, commensality was not just experienced by the human consumers at a meal, but also included the divine participants as well. A striking example of this commensality also takes place in Isaiah 65:

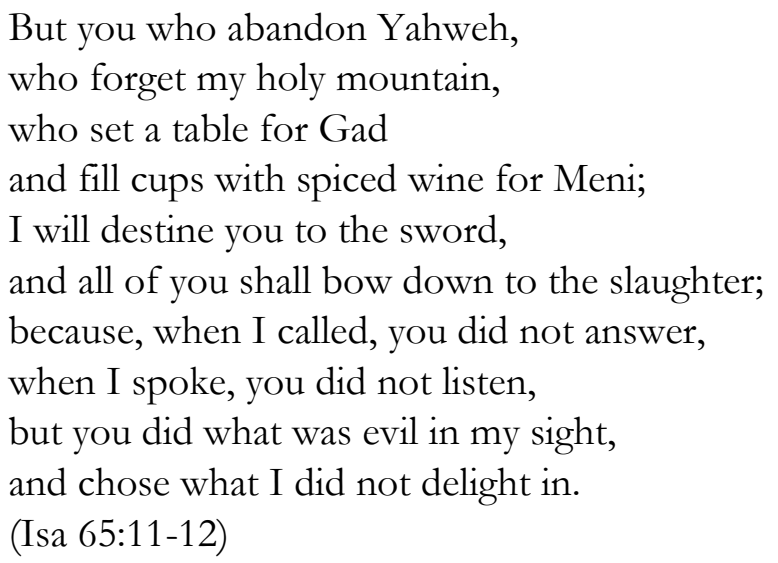

In this text, the exclusion of Yahweh is explicitly stated in contrast to the inclusive commensality experienced with the deities Gad and Meni. Food is set on the table and cups of wine are served for the benefit of the two deities, meanwhile Yahweh is abandoned and forgotten. This prophetic text warns its audience of the dire consequence such consumption and commensality will have: death. In the final lines of this passage, the consumption is characterised as not only disobedient but "evil." Consumption with deities that are not Yahweh is thus conferred a deviant label by the authors of this text. This acts as a means to communicate the boundaries of the community, and verbalises the means by which that community will stay intact, by killing any who would seek out commensality with deities and exclude Yahweh. Another prophetic text uses similar tactics to prevent this kind of deviant consumption.

Chapter 18 of Ezekiel seeks to explicate Yahweh's system of divine retribution for the nation of Israel. To do so the writer gives the

${ }^{34}$ Carol Meyers, "Feast Days and Food Ways: Religious Dimensions of Household Life" in Family and Household Religion: Toward a Synthesis of Old Testament Studies (Winona Lake: Eisenbrauns, 2014), 242. 
example of a son who commits a number of wrongdoings including having intercourse with another man's wife, robbery, and oppressing the poor, but this list also includes lifting his eyes to "shit-gods" and "eat[ing] upon the mountains" (18:10-12). ${ }^{35}$ As a result of these actions the son will be punished: "he shall surely die; his blood shall be upon himself' (v. 13). By contrast, a man who does not do these things will live (18:5-9, 14-17). The expression of eating upon the mountains is particularly interesting given the focus on mountains throughout Ezekiel. ${ }^{36}$ Ezekiel 6:1-7 is particularly concerned about the activities taking place on the mountains and uses a range of pejorative terms to refer to the objects that will be destroyed (במות, גלוליכם (shit-gods), חמניכם). Eating upon the mountains thus appears to be used as a kind of shorthand for the worship activities and commensality that the text deems to be non-Yahwistic. Indeed, the presence of the altars that are mentioned several times $(6: 4,5,6)$ indicate that the sacrifice of animals and other food items was being performed, and likely culminated in a shared cultic meal.

It is relevant that the text prefers the term "shit-gods" to refer to the deities with whom the mountaintop worshipers consume; the mixing of food with the digested and excreted remains of previously consumed food is intentionally unappetising. In anthropology, disgust has been observed as a reaction that creates or marks moral boundaries effectively because of the intimate way in which disgust is felt in the body. ${ }^{37}$ Disgust naturalises and thus moralises difference through its material nature, so as food has an intimate relationship to the body it is a common site of disgust. ${ }^{38}$ So too is faeces when in proximity. ${ }^{39}$ This disgust can intensify discourses of deviance. The pairing of food and excrement, and indeed referring to deities as

\footnotetext{
${ }^{35}$ Ezekiel frequently refers to non-Yahwistic deities as shit-gods (גלולילים), a powerfully pejorative label stemming from גלרים, faeces. This term is commonly translated as "idols" which obscures the vulgarity of the Hebrew. See Francesca Stavrakopoulou, King Manasseh and Child Sacrifice: Biblical Distortions of Historical Realities (Berlin: De Gruyter, 2004), 162, n. 88.

${ }^{36}$ David Casson, The Mountain Shall be Most Holy: Metaphoric Mountains in Ezekiel's Rhetoric (Dissertation, Emory University, 2004), 1-4.

${ }^{37}$ Deborah Durham, "Disgust and the Anthropological Imagination," Ethnos 76 (2011): 136-7.

${ }^{38}$ Durham, "Disgust and the Anthropological Imagination," 131, 137.

${ }^{39}$ Durham, "Disgust and the Anthropological Imagination," 148.
} 
excreted food, in both Ezekiel 18 and 6 intensifies the deviance that the author confers onto this particular group. From a sociological perspective, the Israelites on the mountains are not doing anything innately "wrong," but the way the author of Ezekiel portrays them is deviant; their consumption does not align with the worldview of those with the power to compose these texts. The deviance of the consumers is successfully delivered in the text by demonstrating the negative reaction that will occur (death) in response to the behaviour that the writer has constructed as deviant using pejorative, or stigmatising, language.

\section{Deviant Commensality}

Simmel demonstrates that the great social value of the shared meal is most clearly manifested in the existence of "probibitions of commensality." 40 He gives the example from the eleventh century of the Cambridge Guild, which decreed a penalty for those who would eat and drink with a murderer of a fellow member of the guild, as well as prohibitions of shared meals between certain Hindu castes, and between Christians and Jews in thirteenth century Vienna. ${ }^{41}$ Before proceeding with biblical cases, another anthropological insight is illuminating here. The ethnographic work of Jon Holtzman provides a detailed example of the prohibitions of commensality in the case of the murran of the Samburu of Northern Kenya. Murranhood is a prolonged period of bachelor warriorhood, usually between the ages of fifteen to twenty, during which the men's duty is to defend the community and hunt for animals in the bush to provide for the wider community. ${ }^{42}$ However, the murran must eat only in the company of other murran and cannot eat any food that has been seen by women, prohibiting any consumption with women. ${ }^{43}$ These rules, and the commensality between murran, are viewed as creating solidarity between murran members and inculcating the value of thinking of oneself only in relation to

\footnotetext{
${ }^{40}$ Symons, "Simmel's Gastronomic Sociology," 346. Emphasis in original.

${ }^{41}$ Symons, "Simmel's Gastronomic Sociology," 346.

42 Holtzman, Uncertain Tastes, 77.

${ }^{43}$ Holtzman, Uncertain Tastes, 82-83.
} 
others. ${ }^{44}$ Violating these commensality rules, particularly by eating in their mother's house, risks their claim to murranhood and is also deemed to be "shameless and emasculating." 45 Murran who eat at home are also thought to be ineffective in their ability to defend the community against animals, they are perceived as cowardly, and as having so little shame that they will take children's and elders' food by force. ${ }^{46}$ Violating prohibitions of commensality has far-reaching repercussions for the rest of the community, which is why the rigid structures of murranhood consumption are maintained. For the murran, commensality communicates something broader about commitment to the group as a network of others. With whom you do and do not eat fundamentally structures both your identity and your relationship to others.

Advice relating to the idea of prohibited commensality appears in the texts of Proverbs:

Hear, my son, and be wise, and direct your heart in the way.

Do not be among deviant wine drinkers (בסבאיייין), or among deviant eaters of meat (בזוללי בשר);

for the deviant drinker (בבא) and the deviant eater (זולל) will be dispossessed, and ritual sleep will clothe them with rent pieces. (Prov 23:19-21)

He who keeps the law is a son of understanding, but companions of deviant eaters (זוללים) shame their parents.

(Prov 28:7)

\footnotetext{
${ }^{44}$ Holtzman, Uncertain Tastes, 83.

${ }^{45}$ Holtzman, Uncertain Tastes, 78, 83, 158, 160.

${ }^{46}$ Holtzman, Uncertain Tastes, 83-84.
} 
These texts advise that one should not "be among," or have as "companions," those who eat and drink in a deviant manner. ${ }^{47}$ Given the powerful identity-constructing role of food, it is to be expected that shared food deviancy would act as a potent way of forming shared deviant identities between those who are rendered deviant by the larger, more powerful group. Unlike the texts discussed above, death is not used as a deterrent to prevent the commensality that is deemed deviant. Instead, the would-be eating companion in Prov 23:19-21 is warned that deviant consumers will be dispossessed, probably of the land, and will experience some kind of rending of their clothes. Rending clothing typically signifies a time of great trauma such as mourning or, for example, exile and Temple destruction (Jer 41:4-5; Zech 7:4-5), and is also used when Saul has the kingdom of Israel "torn" from him (1 Sam 15:26-28). Ultimately, these images of rending and dispossession are evocative, at least figuratively, of serious disruption to the stability and social wellness of the relationship between Yahweh and humanity. Thus, it can be inferred that a similar kind of social disruption is likely meant as a consequence to the deviant eater in Proverbs 23. This is significant because in these texts the commensality between the human parties is what is being prohibited. In other words, the text is conscious that simply eating with other deviant eaters is a threat to the social cohesion of the non-deviant community. The negative penalties created by deviant consumption would likely affect the people as a whole, which is why it was perceived so imperative to maintain rigid boundaries that limited or prevented threats to the integrity of the relationship between Yahweh and his people. Deviant consumption could bring disruption to the community, but this could be prevented if individual deviant eaters were kept beyond the borders of the social group.

\footnotetext{
${ }^{47}$ For a detailed discussion of the terminology and translation of this passage see Rebekah Welton, "He is a Glutton and a Drunkard:" Deviant Consumption in the Hebrew Bible (Leiden: Brill, 2020), 269-77. The common renderings of "gluttons/gluttonous eaters" and "drunkards" are fraught with anachronistic baggage relating to modern ideas of self-control. "Deviant eaters" and "deviant drinkers" identifies these behaviours as non-normative for the ancient authors of these texts.
} 
In the second text, Prov 28:7, a slightly different ramification for commensality with the deviant eater is mentioned, that of bringing shame to parents. Here, the unit affected by the deviance is smaller than in the examples addressed above, the family unit or household is instead in view. Eating with others who are deemed deviant implies that the parents are excluded from that commensal event, just as Yahweh is excluded from the commensality of the Israelites when they eat with other deities. This exclusion may indeed produce shame for parents in a culture where meal sharing within household units is viewed as vital to the social cohesion and maintenance of the broader community. The perceived importance of family meals to the wellbeing of society is an ideal that continues to pervade even modern day hegemonic attitudes towards family dinners. ${ }^{48}$ Nevertheless, in biblical texts there are further significances for the parents of deviant eaters where accounts of the societal response and treatment of deviants is portrayed.

\section{Deviant Consumption in Yahweh's Cult}

The priests Hophni and Phineas, sons to the high priest Eli, are reported as consuming the portions of the sacrifices brought to the altar at Shiloh for burning as an offering to Yahweh:

Now the sons of Eli were sons of wickedness; they had no regard for Yahweh or for the duties of the priests to the people. When anyone offered sacrifice, the priest's servant would come, while the meat was boiling, with a threepronged fork in his hand, and he would thrust it into the pan, or kettle, or caldron, or pot; all that the fork brought up the priest would take for himself. This is what they did at Shiloh to all the Israelites who came there. Moreover, before the fat was burned, the priest's servant would come and say to the one who was sacrificing, "Give meat for the priest to roast; for he will not accept boiled meat from you, but only raw."

\footnotetext{
${ }^{48}$ Richard Wilk, "Power at the Table: Food Fights and Happy Meals," Cultural Studies: Critical Methodologies 10 (2010): 430-31.
} 
And if the man said to him, "Let them burn the fat first, and then take whatever you wish," he would say, "No, you must give it now; if not, I will take it by force." Thus the sin of the young men was very great in the sight of Yahweh; for they abhorred Yahweh's portion. (1 Sam 2:12-17)

The author of this text provides a tremendous amount of detail about the deviant eating of Eli's sons. Their misuse and incorrect distribution of the meat is extremely disturbing to the text's authors. The two priestly sons ignore the "food rules" that apportion certain parts of a sacrificial animal for consumption by different parties. Yahweh, the priests, and the offerer are meant to have specific prescribed portions of the carcass, but instead of following the norms of distribution Hophni and Phineas take for themselves any of the meat that comes out of the pot on the fork. In addition, the fat, being the best part of the animal and thus reserved for Yahweh, is also consumed by the two sons and thus is denied to Yahweh.

The division and consumption of certain parts of an animal by different participants creates and endorses hierarchical identities and social relationships between different members of the social group. Anne Katrine de Hemmer Gudme articulates this idea: "The different participants in the meal do share the same animal, but they receive very different portions, and in this difference there seems to be a message about the fundamental ontological difference between god and man." ${ }^{49}$ By refusing to allocate the best, fatty portions to Yahweh, Hophni and Phineas disrupt the social ordering of cultic consumption because they prevent the food portions from inculcating and maintaining the intended identities and statuses of the commensal participants. Instead, the sons consume the best portions, the fatty tissue, and even when the offerer complains about the way in which his sacrificial meat should be apportioned, they refuse. In response, Yahweh sends a messenger to Eli who says: "Why do you kick at my sacrifices and my offerings that I commanded, and honour your sons more than me by nourishing

${ }^{49}$ de Hemmer Gudme, "If I Were Hungry," 178. 
yourselves on the choicest parts of every offering of my people Israel?" (1 Sam 2:29). In eating the food meant for Yahweh, the men gain the identity, prestige and honour that that particular choice portion of food inculcates and communicates to the community. The food is nourishing-physically and socially.

Eli, the father, seems to be included by Yahweh in the deviant behaviour of his sons, perhaps alike to the way shame is also brought upon the parents in Prov 28:7. As a result, Eli's entire house will be punished alongside Hophni and Phineas: "For I have told him that I am about to punish his house forever, for the iniquity that he knew, because his sons were blaspheming God, and he did not restrain them. Therefore, I swear to the house of Eli that the iniquity of Eli's house shall not be expiated by sacrifice or offering forever" (1 Sam 3:13-14 cf. 1 Sam 2:31-33). The fact that Yahweh kills Eli and his entire house suggests that the deviant consumption of the sons was so disruptive to the social structure that the deaths of the sons alone would not be effective in re-establishing the social order. Holtzman recognises that in cultures that have highly regulated patterns of food distribution and consumption the mistreatment of food signifies broader social concerns: "In a society disproportionately constituted through alimentary structures that shape facets of right action and moral personhood, a disruption of proper eating is a broad and potent threat to morality." ${ }^{, 50}$ It is the case that the texts of the Hebrew Bible are particularly concerned with food usage, ${ }^{51}$ which is not unexpected in an ancient context where food security was not guaranteed and thus was entangled with perceived dependencies on the fertility and benevolence of the deities. As such, communities were at pains to maintain proper structures of eating in relation to social order, as to do otherwise threatened to bring about food shortages should the deities become angered or insulted. The anxieties around proper food consumption were particularly potent

\footnotetext{
${ }^{50}$ Holtzman, Uncertain Tastes, 161.

${ }^{51}$ For example, food purity laws (Lev 11; Deut 14:3-21), tithing laws (Deut 14:22-29; Ex 34:22-26; Lev 23:9-22), agricultural laws (Lev 25:1-12; Deut 22:9-11), sacrificial and festal laws (Deut 26:1-15; Lev 4:135; Ex 12:1-27), gleanings (Lev 19:9, 23:22).
} 
for households, who were of course responsible for their own daily food and survival, and this is perhaps evident in the concern parents had about the deviant consumption of their children.

\section{Dealing with a Deviant Consumer}

In Deut 21:18-21 a hypothetical case of a so-called Rebellious Son is recounted:

If someone has a rebellious and defiant son who will not obey the voice of his father and mother, who does not heed them when they discipline him, then his father and his mother shall take hold of him and bring him out to the elders of his town at the gate of that place. They shall say to the elders of his town: "This son of ours is rebellious and defiant. He will not obey us. He is a deviant eater (סולל) and a deviant drinker (סבא)." "52 Then all the men of the town shall stone him to death with stones. So you shall purge the evil from your midst; and all Israel will hear and fear.

In this text, it difficult to identify whether the deviant consumption the Rebellious Son has participated in is alike to those who eat with other deities, or whether it is more similar to the actions of Hophni and Phineas who fail to follow the established food rules in Yahweh's own cult. It is also impossible to know if this represents a common occurrence and practice, or if this is merely a literary invention that was never applied historically. ${ }^{53}$ Whatever the case, this text provides some insight into how the text's authors might have preferred a community to treat a deviant consumer. Sociologist Kai Erikson asserts that when dealing with a deviant offender, societies will organise a formal ceremony to confront the threatening behaviour, reassert the community boundaries and reinforce the violated

\footnotetext{
${ }^{52}$ Note that the Hebrew is the same here as in Proverbs 23:19-21 and 28:7 discussed above. The terms are discussed at length in Welton, "He is a Glutton," 255-277.

${ }^{53}$ Douglas A. Knight, Law, Power, and Justice in Ancient Israel (Louisville: Westminster John Knox Press, 2011), 242.
} 
hegemony. ${ }^{54}$ The ceremony consists of three general parts, which seems to dovetail with the case of the Rebellious Son:

To begin with, the community's decision to bring deviant sanctions against one of its members is not a simple act of censure. It is an intricate rite of transition, at once moving the individual out of his ordinary place in society and transferring him into a special deviant position. The ceremonies which mark this change of status, generally, have a number of related phases. They supply a formal stage on which the deviant and his community can confront one another (as in the criminal trial); they make an announcement about the nature of his deviancy (a verdict or diagnosis, for example); and they place him in a particular role which is thought to neutralize the harmful effects of his misconduct (like the role of prisoner or patient). These commitment ceremonies tend to be occasions of wide public interest and ordinarily take place in a highly dramatic setting. ${ }^{55}$

In the case of Deut 21:18-21, the way the deviancy is treated is highly dramatic and incorporates public participation. Like in previous examples, the parents are explicitly mentioned, though this time they actively try to eliminate the deviant threat, lest they be tarred with the same brush. The mother and father seize their son and bring him to the elders; the specific crime of deviant consumption is declared; and in order to "neutralise" the deviancy, or purge the evil, the men of the town stone the son to death. The law ends by saying "all Israel will hear and fear," which has some similarity to Yahweh's declaration before the deaths of Hophni and Phineas: "I am about to do something in Israel that will make both ears of anyone who hears of it tingle" (1 Sam 3:11). The hearing and fearing/tingling appears to link the knowledge of deviance with a tangible change in the community. The deaths of the deviant consumers is explicitly intended to be something communicable across the social group,

${ }^{54}$ Erikson, Wayward Puritans, 13.

${ }^{55}$ Erikson, Wayward Puritans, 15-16. 
they are explicitly means for informing Israel about what behaviour is acceptable by publicly identifying and eliminating deviance.

In his analysis of the seventeenth century Puritans of Massachusetts, Erikson notes that the young settler community were "experiencing a shift in ideological focus" which called for the trial and banishment of a deviant figure named Anne Hutchinson. ${ }^{56}$ It is during times of shifting identities and ideologies that objections to institutions of authority and deviation from the status quo become more threatening. The ideology of centralisation that Deuteronomy appears to initiate, particularly in chapter 12 but also 14:22-26, is perhaps key to the underlying context in which these occurrences of deviant consumption emerge. Within the sociological study of deviance it is particularly important to acknowledge the role of power in the creation of laws or cultural reactions that render behaviours deviant; the greater the power of the people who react to something as deviant, the more deviant that thing becomes. ${ }^{57}$ Those in power in Iron Age Israel and Judah were more able to produce texts and thus state what they deemed to be deviant. It would not have benefitted those who relied on the economic turnover of the Temple, who likely had more power and influence, to allow uncontested sacrifices at other altars, to other gods. ${ }^{58}$ Indeed, Goode points out that "the powerful are able to ensure that laws favorable to their own interests, and detrimental to the interests of other, less powerful groups and classes, are passed and enforced." 59 However, the shift to a centralised, Yahweh-alone ideology was relatively new, and as such was vulnerable to the objections of those who held to the traditional worship of many gods, at many altars. ${ }^{60}$ Thus, the conferring of deviant labels onto threatening individuals was probably deemed necessary in order to bolster the power of those who benefitted from

\footnotetext{
${ }^{56}$ Erikson, Wayward Puritans, 101.

${ }^{57}$ Erich Goode, Deviant Behavior (New York: Routledge, 2016), 19.

58 Those who benefitted being the cultic professionals at temples and shrines. Harold V. Bennett, Injustice Made Legal: Deuteronomic Law and the Plight of Widows, Strangers, and Orphans in Ancient Israel (Grand Rapids: Eerdmans, 2002) 162-172; Knight, Law, Power, and Justice, 239-240, 256.

${ }^{59}$ Goode, Deviant Behavior, 64.

${ }^{60}$ Bennett, Injustice Made Legal, 154; Knight, Law, Power, and Justice, 234-235.
} 
the sacrifices of the centralised temple system and its underpinning legal framework. ${ }^{61}$

It would be beneficial to have comparative ancient examples of deviant consumption to better contextualise this sociological phenomenon in Israel and Judah, but examples are few. In tablet II line 5 of the Mesopotamian $\breve{S} u$ pu $u$ text there is an invocation to the gods to release a suffering man who has "eaten what is preserved to his god." 62 This would suggest that there certainly was some expectation that people would not consume food that was meant to be offered to a deity, however the text does not render such an individual deviant in the way seen in the above Hebrew Bible examples. Without evidence of the societal reaction that renders such a person deviant then there is no deviance. ${ }^{63}$ The most likely neighbouring context we would expect to find evidence of deviant consumption would be in Akhenaten's reign of the New Kingdom of ancient Egypt during which the worship of deities other than the Aten was banned. ${ }^{64}$ Unfortunately, no explicit evidence confirms this, likely due to the unpopular nature of Akhenaten's monotheistic rule in wider society and the enthusiastic return to polytheism seen during the subsequent reign of his son Tutankhamun. ${ }^{65}$ Overall, it appears that the deviantisation of the worship of multiple deities is largely unique to Israelite and Judahite cultures among the religions of ancient southwest Asia and Egypt, ${ }^{66}$ however further research would be beneficial in the area of deviant consumption.

\footnotetext{
${ }^{61}$ Knight, Law, Power, and Justice, 240, 256; Bennett, Injustice Made Legal, 162-172.

${ }^{62}$ Erica Reiner, Šurpu: A Collection of Sumerian and Akkeadian Incantations (Graz: Biblio Verlag, 1958), 13; Barbara Böck, "On the Ancient Mesopotamian Concept of 'Taboo': Transgression and Delimitation," in Borders: Terminologies, Ideologies, and Performances (Tubingen: Mohr Siebeck, 2016), 312.

${ }^{63}$ Goode, Deviant Behavior, 5.

${ }^{64}$ Robert W. Butler, "Akhenaten, the Damned One: Monotheism as the Root of all Evil," in Constructing Good and Evil, (Oxford: Inter-Disciplinary Press, 2011), 13; Tarmo Kulmar, "On a Possible Characteristic of the Governing System of Pharaoh Amenhotep IV (Akhenaten)," Folklore: Electronic Journal of Folklore 74 (2018): 119.

${ }^{65}$ Butler, "Akhenaten, the Damned One," 13-16.

${ }^{66}$ Good, Edwin M. "Capital punishment and its alternatives in Ancient Near Eastern Law," Stan. L. Rev. 19 (1966): 970.
} 


\section{Conclusions}

The deviantisation of certain consumption practices in ancient Israel and Judah is inextricably linked to the negotiation of power between the authors of the biblical texts and the majority of the population who laboured for produce and livestock. Interweaving this economic motivation is also the metaphysical belief of the deity's participation in communal sacrifices and meals. Due to the highly social nature of meal sharing and the phenomenon of commensality that creates inclusive and exclusive social bonds, the identity of the deity present at a meal was significant to the authors of biblical texts. In Israel and Judah, like in many cultures, right ways of eating have broader social and moral ramifications, particularly because of the precarious and labour-intensive nature of food production. Eating with the right people and deity, and eating the right food, was deemed from the authors' perspectives to create positive relationships between Yahweh and the people, ensuring social cohesiveness. Using a sociological approach to deviancy helps us to focus on the reaction to the behaviour and assess what underlying socio-economic currents account for that reaction by powerful authors, as opposed to focusing on any inherent "wrong" in the individual, which would tell us little about the wider social context. Yahweh is depicted as frequently suffering from food envy, and this reaction by Yahweh was one of the key literary methods used to classify and curtail deviant consumption for the benefit of those in power. 